\title{
Membangun Karakter Dalam Perayaan Budaya Lokal Di Kabupaten Takalar
}

\author{
Rudi Amir \\ Jurusan Pendidikan Luar Sekolah Fakultas Ilmu Pendidikan Universitas Negeri Makassar \\ rudiamir7706@gmail.com
}

\begin{abstract}
ABSTRAK
Budaya lokal pada suatu masyarakat merupakan identitas dan jati diri bagi mereka. Keberadaan budayaan dalam suatu masyarakat, menunjukkan bahwa mereka sebagai suatu masyarakat memiliki suatu hasil karya, rasa dan cipta yang patut mereka banggakan. Budaya lokal dalam pelaksanaannya memiliki nilai dan kemampuan membangun karakter bangsa bagi masyarakatnya, sebagimana perayaan maudu lompoa dan appaddekko memiliki kekuatan pendorong dalam membangun karakter masyarakat yang merayakannya. Ada beberapa karakter yang dibangun dalam perayaan budaya tersebut yang dapat diamati antara lain, gotong-royong, rasa persatuan, menghargai perbedaan dan kesetaraan, kerja keras dan persaudaraan. Oleh karena itu, sudah sepantasnya budaya lokal dilestarikan dan diberi ruang yang luas untuk berkembang, karena dapat menjadi media transformasi pendidikan karakter bagi generasi muda.
\end{abstract}

Kata Kunci: Budaya Lokal, Transformasi Budaya, Perayaan Maulid, Pesta Panen

\section{PENDAHULUAN}

Manusia adalah makhluk sosial, dimana manusia tidak bisa melepaskan dirinya dari kehidupan bermasyarakat. Kehidupan sehari-hari manusia dalam lingkungan masyarakat tidak lepas dari kebudayaan, sebab stiap saat selalu berurusan dengan hasil-hasil kebudayaan.

Selo Sumardjan dan Soelaeman Soemardi (Wulansari, C. D. 2013: 76) mengemukakan bahwa kebudayaan merupakan semua hasil dari karya, rasa dan cipta masyarakat. Masyarakat menciptakan teknologi untuk dapat menguasai alam untuk dipergunakan hasilnya bagi keperluan masyarakat (material culture), Rasa meliputi jiwa manusia mewujudkan segala norma dan nilai kemasyarakatan yang perlu untuk mengatur masalah kemasyarakatan dalam arti luas, seperti agama, ideologi, kebathinan, kesenian dan hasil ekspresi jiwa manusia yang hidup sebagai anggota masyarakat.

Masyarakat yang bermukim di Kabupaten Takalar memiliki kebiasaan merayakan maulid dan pesta panen dengan caranya sendiri. Perayaan maulid dan pesta panen merupakan suatu kebiasaan atau ritual yang dilakukan secara turun temurun. Perayaan budaya tersebut merupakan ciri khas bagi masyarakat yang melaksanakannya setiap tahun.

Perayaan budaya lokal tersebut, tidak sekedar ritual tahunan yang berlangsung tanpa makna, akan tetapi memiliki nilai pendidikan karakter bangsa di dalamnya, seperti gotongroyong, solidaritas, rasa persatuan, tolong menolong, kerja keras, cinta lingkungan dan lainlain. Nilai-nilai karakter bangsa yang ditransformasi dari generasi ke generasi melalui perayaan budaya lokal masyarakat Kabupten Takalar menjadi pendorong untuk tetap melestarikan budaya tersebut.

Rumusan masalah dalam penelitian ini adalah (1) bagaimana gambaran nilai karakter bangsa pada perayaan maudu lompoa di Desa Cikoang Kabupaten takalar?, (2) bagaimana gambaran nilai karakter bangsa pada perayaan appaddekko di Kelurahan Sabintang Kabupaten Takalar?.

Kajian pustaka yang menjadi dasar dalam tulisan ini adalah mengenai pendidikan karakter dan budaya lokal. Megawangi (2005: 95) merangkum berbagai teori dan menuangkannya dalam sembilan pilar karakter meliputi: (1) cinta Tuhan dengan segala ciptaannya (love Allah, trust, reverence, loyalty), (2) kemandirian dan tanggung jawab (responsibility, excellence, self reliance, dicipline, orderliness), (3) kejujuran, amanah dan bijaksana (trustworthiness, reliability and honesty), (4) hormat dan santun (respect, courtessy, obedience), (5) dermawan suka menolong dan gotong royong (love compassion, caring empathy, generousity, moderation, cooperation), (6) percaya diri kreatif dan pekerja keras (confidence, assertiveness, creativity, resourcefullness, courage, determination, and enthusiasm), (7) kepemimpinan dan keadilan (justice, fairness, mercy, leadership), (8) baik dan rendah hati 
(kindness, friendliness, humility, modesty), dan (9) toleransi, kedamaian dan persatuan (tolerance, flexibility, peacefullness, unity).

Terkait dengan penidikan karakter dan pembentukan akhlak mulia ini, Pemerintah telah pula memberikan respon positif dengan digulirkannya Kebijakan Nasional Pembangunan Karakter Bangsa yang berisi tentang arah kebijakan, kerangka dasar, tahapan serta strategi yang digunakan dalam pembangunan karakter bangsa. Sebagaimana tercantum dalam panduan pelaksanaan pendidikan karakter oleh Pusat Kurikulum dan Perbukuan Kemendiknas (2011: 8) bahwa terdapat 18 nilai yang perlu dikembangkan pada diri seorang anak yaitu: (1) religius, (2) jujur, (3) toleransi, (4) disiplin, (5) kerja keras, (6) kreatif, (7) mandiiri, (8) demokratis, (9) rasa ingin tahu, (10) semangat kebangsaan, (11) cinta tanah air, (12) menghargai prestasi, (13) bersahabat, (14) cinta damai, (15) gamar membaca, (16) peduli lingkungan, (17) peduli sosial, dan (18) tanggungjawab.

Terkait konsep budaya lokal, Ihromi (2013: 18) mengemukakan bahwa kebudayaan merupakan seluruh cara kehidupan dari masyarakat yang manapun dan tidak hanya mengenai sebagian dari cara hidup itu, yaitu bagian yang oleh masyarakat dianggap lebih tinggi atau lebih diinginkan. Yaitu cara hidup yang diterapkan dalam kehidupan masyarakat. Kebudayaan menunjuk pada berbagai aspek kehidupan, yang meliputi cara-cara berperilaku, kepercayaan-kepercayaan dan sikap-sikap, dan juga hasil dari kegiatan manusia yang khas untuk suatu masyarakat atau kelompok penduduk tertentu.

Kebudayaan merupakan tata cara kehidupan manusia untuk memperoleh kesejahteraan hidup dan diwariskan kepada generasi selanjutnya melalui proses belajar yang berlangsung melalui cara-cara masyarakat yang mewariskan budaya tersebut dan berlangsung terus menerus.

Budaya lokal dapat diartikan sebagai bentuk pikiran, akal budi, kemampuan atau kekuatan yang telah menjadi suatu kebiasaan dalam masyarakat lokal. Budaya lokal dapat dapat pula diartikan sebagai kearifan lokal (lokal wisdom), Panjaitan, dkk (2014, hlm.115) memberi arti "kearifan lokal sebagai gagasangagasan setempat yang bersifat bijaksana, penuh kearifan, bernilai baik, yang tertanam yang diikuti oleh masyarakatnya.

Keraf (2002), firmansya (2011) yang dikutip oleh Maryani, E dan Yani, A. (2015, hlm.116) mengemukakan kearifan lokal (lokal wisdom) dan Indigenous knowledge memiliki makna yang sama. Kearifan lokal diartikan sebagai semua bentuk keyakinan, pemahaman, atau wawasan serta adat kebiasaan atau etika yang menuntun perilaku manusia dalam kehidupan di dalam komunitas ekologis. Indigenous knowledge mencakup kebiasaan, pengetahuan, persepsi, norma, kebudayaan yang dipatuhi bersama suatu masyarakat (lokal) dan hidup turun-temurun. Wujud dari kearifan lokal dapat berbentuk sistem pengetahuan, sistem sosial, dan sistem budaya, tercermin dari pengelolaan lingkungan, adat istiadat yang mengatur hubungan sosial, dan hasil kebudayaan artefak seperti tata guna lahan, bahan dan arsitektur rumah tinggal, gaya dan corak pakaian, perabotan, dan upacara-upacara mengantar siklus kehidupan.

\section{METODE PENELITIAN}

Penelitian ini menggunakan pendekatan penelitian kualitatif, yaitu suatu pendekatan penelitian dalam ilmu-ilmu sosial dan pendidikan. Penelitian kualitatif dapat membuat peneliti memotret fenomena secara luas dan mendalami sesuai dengan apa yang terjadi dan berkembang pada situasi social. "Gejala yang diteliti bersifat holistik berdasarkan keseluruhan situasi social yang diteliti meliputi aspek tempat (space), pelaku (actor), dan aktivitas (activity) yang berinteraksi secara sinergis" (Sugiyono 2013, hlm.206).

Subjek penelitian dalam penelitian ini adalah Masyarakat Desa Cikoang yang merayakan budaya Ma'udu Lompoa (Maulid Besar), dan Masyarakat Kelurahan Sabintang yang merayakan appaddekko sebagai acara pesta panen di Kabupaten Takalar.

\section{HASIL \& PEMBAHASAN \\ 1. Nilai karakter bangsa pada kegiatan Appaddekko sebagai budaya pesta panen}

Apabila kita menyebut Kata Appaddekko (bahasa Makassar) dan mappadendang (bahasa Bugis), sebagai masyarakat bugis-makassar pasti sudah bisa membayangkan bahwa "Appaddekko" merupakan acara pesta panen raya bagi masyarakat Bugis-Makassar. Appaddeko adalah kegiatan menumbuk padi yang dalam bahasa makassarnya di sebut "Addengka" dalam wadah lesung yang dalam bahasan makassarnya di sebut "Assung" yang berukuran \pm 5 meter.

Appaddekko dilakukan oleh 3-5 orang sebagai penumbuk padi dengan menggunakan sepotong bambu atau balok yang panjangnya \pm 1,5 meter dan 1 orang yang bertugas sebagai pemukul lesung dibagian depan yang disebut 
dalam bahasa makassar sebagai "padudu", yang memukul lesung dengan sepotong balok atau bambu yang berukuran $\pm 1,5$ meter serta 1 orang pemukul lesung dibagian belakang lesung yang dalam bahasa Makassar di sebut sebagai "Papeppe", menggunakan dua alat tertentu seperti batu atau benda lain dengan memukul secara bergantian pada sisi samping kiri dan kanan lesung. Jadi secara keseluruhan jumlah orang yang melakukan kegiatan Appaddekko atau yang disebut dalam bahasa makassar "Pa Paddekko" berjumlah 5-7 orang.

Saat menumbuk padi (padengka) oleh para penumbuk padi, lesung mengeluarkan bunyi, dan peran "padudu" yang memukul lesung dengan tempo yang cepat mengiringi bunyi yang dihasilkan dari penumbuk padi tersebut , selanjutnya "papeppe" ikut mengiringi irama dari penumbuk padi dan pedudu yang secara keseluruhan terjadi harmonisasi suara yang terdengar sangat merdu dan khas.

Kegiatan Appaddeko dilakukan pada saat memulai acara panen raya. Ada beberapa daerah di Sulawesi selatan yang memiliki budaya Appaddekko, dan mereka memiliki prosesi ritual yang berbeda atau khas berdasarkan kebiasaan yang dilakukan oleh masyarakatnya secara turun temurun. Akan tetapi saat ini sudah tidak banyak daerah yang melestarikan budaya Appaddeko tersebut. Prosesi ritual Appaddeko yang penulis tulis disini berdasarkan yang dilakukan dikampung penulis (Kel. Sabintang, Kab. Takalar). Penulis sadar bahwa prosesi ritual Appaddeko yang cukup panjang pernah dilakukan oleh nenek moyang dikampung penulis. Tapi saat ini sudah banyak yang terlupakan prosesi ritual tersebut dan sudah disederhanakan prosesnya. Dan saat ini proses yang telah disederhanakan tersebut, yaitu kegiatan appaddeko dimulai dengan adanya instruksi dari tokoh masyarakat yang menentukan kapan acara Appaddeko dilakukan dan selanjutnya warga masyarakat menindak lanjuti dengan memulai proses pengambilan padi yang sudah tua atau menguning dengan batang-batangnya di pagi hari pada hari yang telah ditentukan tersebut, setelah itu padi tersebut dipisahkan dari batangnya dan dikukus sampai matang dan selanjutnya padi tersebut digoreng tanpa menggunakan minyak atau disangrai dan setelah itu didinginkan untuk dilakukan kegiatan Appaddekko.

Appaddeko biasanya hanya dilakukan satu kali dalam setahun pada saat panen padi di awal tahun dan tidak dilakukan pada panen padi pada musim tanam kedua atau dimusim kemarau. Hal ini dilakukan karena musim panen kedua di musim kemarau tetap dianggap satu paket dengan panen sebelumnya, sehingga dianggap tidak perlu untuk melakukan perayaan panen raya.

Appaddeko yang dilakukan dengan kegiatan Adengka, Apadudu dan Ameppe di kerjakan secara bergantian apabila masyarakat yang sedang appaddeko atau Pa Paddekko telah lelah dan ingin digantikan oleh yang lainnya, dan para pengganti tanpa diperintah tetapi secara spontan setelah ada kode dari pelaku atau pa paddekko ingin digantikan karena telah lelah appaddekko dan itu berlangsung secara alami apabila terjadi pergantian $\mathrm{Pa}$ Paddekko selanjutnya.

Appaddeko merupakan salah satu kekayaan budaya masyarakat sulawesi selatan. Walaupun di beberapa kabupaten memiliki budaya Appaddeko dengan prosesi dan ritual masing-masing masyarakatnya. Akan tetapi pada dasarnya Appaddeko memiliki tujuan yang sama mengandung nilai luhur yang sama, walaupun di kemas dengan warna tersendiri berdasarkan ke khasan daerahnya. Berdasarkan analisa penulis tujuan dan nilai yang terkandung dari Acara Appaddekko itu sendiri yaitu, 1) sebagai tanda Rasa syukur atas Limpahan rezeky yang telah diberikan oleh Allah SWT. Ini menandakan akan adanya rasa syukur atas nikmat yang diberikan, baik itu banyak maupun sedikit dan mencari rezeky dengan cara yang halal dengan penuh kerja keras, 2) sebagai penanda bahwa acara panen raya sudah dimulai, sehingga para petani sudah mulai mempersiapkan segala sesuatu yang dibutuhkan untuk kegiatan panen padi. Disni mengandung pesan bahwa segala sesuatu harus dipersiapkan dengan matang sebelum mengerjakannya 3) menumbuhkan rasa cinta dan bangga sebagai masyarakat petani sehingga masyarakat tetap memiliki semangat yang tinggi untuk menumbuhkan produktivitas pertaniannya sebagai penyokong ekonomi bangsa. Nilai yang terkandung disini yaitu pekerjaan harus dilakukan dengan hati. Rasa cinta dan bangga dengan pekerjaan akan mendorong semangat kerja yang lebih tinggi, 4) menjaga hubungan silaturahmi, kebersamaan, rasa solidaritas, kesetiakawanan sosial dalam kehidupan bermasyarakat serta tumbuhnya nilai-nilai demokratisasi. Pada saat kegiatan appaddeko berlangsung, seluruh warga masyarakat berkumpul ditempat dilangsungkannya kegaiatan Appaddeko. Disitulah terlihat adanya keramaian dan terpancar diwajah masyarakat akan rasa senang dan bahagia menikmati suara yang dihasilkan oleh lesung yang ditumbuk dan dipukul secara beraturan dan berirama secara harmonis. Tidak ada lagi pemisahan antara pejabat dan bukan pejabat atau bangsawan dan bukan bangsawan, 
serta pegawai ataupun petani, tetapi pada saat acara tersebut berlangsung semuanya larut dalam kegembiraan menikmati berlangsungnya acara tersebut. Seluruh Warga memiliki kesempatan untuk berpartisipasi sebagai "pa paddekko" ataupun ikut berpartisipasi agar padinya ditumbuk di lesung yang digunakan secara bersama.

Melestraikan budaya sangat penting artinya bagi masyarakat bangsa Indonesia pada umumnya dan propinsi sulawesi selatan pada khususnya. Appaddeko merupakan salah satu budaya yang memiliki nilai dan pesan-pesan moral yang sangat penting untuk dapat dijadikan sebagai penggerak pembangunan bangsa. Apabila kita ingin bangga sebagai negara agraris dan ingin berswasembada pangan, maka nilai-nilai dan yang pesan-pesan moral yang tersampikan melalui acara Appadeko harus tetap dijaga sebagai ciri khas dan kekuatan moral kita saat ini maupun yang akan datang.

\section{Nilai karakter bangsa pada "Maudu Lompoa" sebagai budaya memperingati kelahiran Nabi Muhammad.}

Perayaan maulid berlangsung di sulawesi selatan diselenggarakan pada bulan Rabiul Awal, tepatnya dimulai pada 12 Rabiul Awal. Maulid adalah peringatan kelahiran Nabi Muhaammad SAW yang jatuh pada tanggal 12 Rabiul Awal dan pada tanggal tersebut pula adalah hari wafatnya nabi Muhammad SAW. Kadua peristiwa bersejarah dalam agama islam tersebut merupakan moment yang sangat penting yang berkaitan dengan Nabi Muhammad SAW.

Pemahaman masyarakat cikoang terhadap kelahiran (maulid) Nabi Muhammad SAW bahwa kelahiran itu merupakan pokok yang menjadi sumber dari sumber kelahiran yang lain sesudahnya. Hal ini berarti bahwa keberadaan alam ini beserta semua isinya bersumber dari kelahiran pertama yakni Nur Muhammad. Oleh Karena itu, menurut masyarakat Desa Cikoang, barang siapa menghargai kelahiran Nabi Muhammad SAW pada tanggal 12 Rabiul Awal pada dasarnya pula telah menghargai terjadinya Nur Muhammad yang bersumber dari Nur Allah.

Perayaan maudu lompoa (maulid besar) sangat syarat dengan makna yang terkadung di dalamnya. Bahan yang digunakan dalam perayaan maulid dan proses membuatnya memiliki nilai pendidikan karakter yang sangat dalam. Simbol-simbol makna yang dituangkan dalam perayaan maulid dimaksudkan agar manusia yang melakukan perayaan maulid memiliki kesadaran diri dan selalu berupaya untuk meningkatkan kualitas diri. Peringatan maulid yang dilaksanakan setiap tahun diharapkan menjadi nasehat yang berbentuk simbol agar manusia selalu kembali fitrahnya sebagai manusia dan menyadari diri atas segala kelebihan dan kekurangan pada dirinya, serta memaksimalkan segala potensi yang dimiliki melalui proses pembelajaran.

Beberapa tahap ritual ritual dari perayaan maudu lompoa yaitu: (1) Je'ne-jene Sappara (mandi di Bulan Syafar), (2) anyongko jangang (menyimpan ayam dalam kandang), (3) angngalloi ase (menjemur padi), (4) adedengka ase (menumbuk padi), (5) ammisa' kaluku (mengupas buah kelapa), (6) ammolong jangan (memotong ayam), (7) pamatara berasa sigantang (memasak nasi setengah matang sebanyak 4 liter), (8) ammonei baku (mengisi bakul), (9) annoddo bayao (menusuk telur dengan kayu dari bambu), (10) a'rate (ratib) dan ammaca salawa' (pembacaan shalawat), (10) abbake kanre maudu (membagikan sajian maulid).

Simbol 4 liter beras yang dalam bahasa makassar disebut sigantang, memberi mengisyaratkan akan penciptaan manusia yang terdiri dari 4 unsur yaitu tanah, api, air, dan angin. Makna filosofi empat unsur air, api, tanah dan udara yang berkaitan dengan berbagai karakter manusia yang harus dibangun dengan baik yaitu:

1. Unsur Air yaitu pembawa ketenangan, kesejukan, kedamaian, kemampuan adaptasi, mempersatukan perbedaan, dan kekuatan. Orang yang sedang marah kemudian meminum segelas air akan segera redam amarahnya. Rasa lelah setelah beraktifitas seharian kemudian meminum segelas air akan berubah menjadi segar dan lebih semangat, dan air mampu menyatukan semen dengan pasir dan selanjutnya membentuk kekuatan beton. Tetapi air bisa membawa bencana apabila meluap. Banjir bisa meluluh lantahkan segala apa yang dilalui tanpa pandang bulu.

2. Unsur api: sifatnya berkobar penuh semangat, berdiri tegak menerangi sekitarnya. Ini unsur air dapat disimbolkan dengan ketegasan dalam bersikap, konsisten memegang prinsip, berani karena benar. Tetapi api juga dapat menghanguskan segala sesuatu apabila tidak dikontrol dengan baik. Kobaran api dapat menjadi malapetaka, menghanguskan apa yang dilewati tanpa menyisakan sedikitpun.

3. Unsur tanah. Tanah dapat menumbuhkan semua tumbuhan, tanah tidak pernah membedakan tumbuhan yang ingin tumbuh 
diatasnya kecuali kualitas tumbuhan tersebut. Tumbuhan yang berkualitas baik akan tumbuh dengan baik dan yang berkualitas rendah akan tumbuh dengan kualitas rendah, tanah tidak pernah menumbuhkan suatu tumbuhan dari bibit yang berbeda, tanah akan menumbuhkan tumbuhan dari bibitnya sendiri. Semua makhluk hidup berpijak di atasnya, mencari nafkah dan menggantungkan hidup dari sumber kehidupan dari tanah. Sifat yang tercermin dari tanah adalah mengayomi, merima segala perbedaan, adil, bijaksana, sabar dan jujur. Tetapi apabila tanah tidak dirawat dengan baik, dapat mendatangkan bencana bagi umat manusia seperti longsor.

4. Unsur angin. Angin yang bertiup pelan memberikan kesejukan, ketenangan, kedamaian, kekuatan dan semangat perubahan. Angin atau udara memberikan kehidupan pada semua makhluk hidup dipermukaan bumi ini dan ketiadaan udara menimbulkan kamatian. Angin dapat merubah arah kemiringan pepohonan, dimana angin berhembus semua pohon akan condong ke arah sana. Angin dapat menggerakkan perahu layar dilautan, sehingga pelayaran di laut dapat berjalan dengan baik. Tetapi angin dapat menggerakkan air yang tenang menjadi gelombang tinggi yang ganas, angin dapat berubah jadi badai yang menghancurkan segala sesuatu yang dilewati.
Kesadaran akan diri atas unsur-unsur alam yang terdapat dalam penciptaan diri manusia merupakan inti dari perayaan maulid. Makna yang terkadung di dalam simbol-simbol dalam perayaan maulid merupakan manifestasi sifatsifat atau karakter yang dimiliki oleh Nabi Muhammad SAW yang telah dicontohkan selama hidup dan berinterkasi dalam kehidupan bermasyarakat, berbangsa dan bernegara. Sebagaimana Firman Allah SWT tentang Nabi Muhammad SAW dalam Alquran:

QS. Al-Ahzab : 21 :

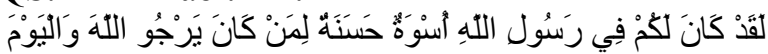

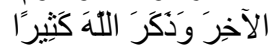

Artinya:

"Sesungguhnya Telah ada pada (diri) Rasulullah itu suri teladan yang baik bagimu (yaitu) bagi orang yang mengharap (rahmat) Allah dan (kedatangan) hari kiamat dan dia banyak menyebut Allah."

Pada intinya, perayaan maulid merupakan ajakan bagi ummat manusia untuk meneladani sifat-sifat atau karakter yang dimiliki oleh Nabi Muhammad SAW yang diyakini oleh umat Muslim sebagai karakter yang patut diteladani untuk kemaslahatan umat manusia. Nilai karakter tersebut dapat ditemukan dalam perayaan maulid yang dilakukan masyarakat Desa Cikoang. Sebagaimana pada tabel berikut.

Tabel 1. Konstruksi Nilai Karakter Bangsa Pada Tahapan Perayaan Maudu Lompoa

\begin{tabular}{|c|c|c|}
\hline No & Nilai Karakter & Tindakan Karakter Pada Perayaan Maudu Lompoa \\
\hline 1. & $\begin{array}{l}\text { Nilai-nilai karakter yang } \\
\text { terkait dengan Tuhan } \\
\text { YME (religius) }\end{array}$ & $\begin{array}{l}\text { 1. Sajian kanre maudu (makanan maulid) sebagai rasa syukur } \\
\text { kepada Allah SWT atas Kelahiran Nabi Muhammad SAW. } \\
\text { 2. Ayam adalah binatang yang ada di arasy, dan ayam } \\
\text { merupakan binatang yang memiliki keistimewaan karena } \\
\text { membangunkan manusia pada waktu subuh untuk bisa } \\
\text { menunaikan ibadah sholat subuh. Ayam diibaratkan sebagai } \\
\text { ruh manusia. } \\
\text { 3. Telur merupakan simbol kelahiran dari Nabi Muhammad } \\
\text { SAW. } \\
\text { 4. Empat liter beras merupakan simbol penciptaan manusia yang } \\
\text { terdiri dari empat unsur alam, yaitu: Tanah, Angin, Air, dan } \\
\text { Api. }\end{array}$ \\
\hline 2. & $\begin{array}{l}\text { Nilai-nilai Karakter } \\
\text { yang terkait dengan } \\
\text { adab terhadap diri } \\
\text { sendiri }\end{array}$ & $\begin{array}{l}\text { 1. Kemandirian dan kerja keras tercermin dari segala sajian } \\
\text { untuk perayaan maulid harus dilakukan sendiri, seperti padi } \\
\text { sebaiknya ditumbuk sendiri bukan, minyak harus dari hasil } \\
\text { buatan sendiri dan berasal dari pohon kelapa sendir. } \\
\text { Demikian pula bakul dan tepa'-tepa' harus dibuat sendiri. } \\
\text { 2. Kreatifitas tercermin dari Kanre maudu (sajian maulid) dibuat } \\
\text { seindah mungkin agar kelihatan indah dan menarik sehingga }\end{array}$ \\
\hline
\end{tabular}




\begin{tabular}{|c|c|c|}
\hline & & $\begin{array}{l}\text { mendatangkan kesenangan dan kegembiraan bagi yang } \\
\text { merayakan maulid. } \\
\text { 3. Rasa tanggungjawab tercermin dari kemauan yang tinggi } \\
\text { untuk menjaga kebersihan setip bahan dan makanan yang } \\
\text { akan disajikan. Tidak boleh ada satupun bahan dan makan } \\
\text { yang dikotori oleh najis, karena akan merusak makna } \\
\text { kesucian dari kelahiran Nabi Muhammd SAW. }\end{array}$ \\
\hline 3. & $\begin{array}{l}\text { Nilai-nilai tentang } \\
\text { hubungan dengan } \\
\text { sesama }\end{array}$ & $\begin{array}{l}\text { 1. Pembagian kanre maudu merupakan sautu cara untuk saling } \\
\text { berbagi atas rezeky yang dimiliki. Kaum miskin dapat } \\
\text { merasakan nikmatnya makan pada saat perayaan maulid } \\
\text { karena mereka bisa mengambil sajian maulid sudah dirateki } \\
\text { atau di bacakan surat tentang perjalanan nabi dalam } \\
\text { menyiarkan agama islam. } \\
\text { 2. Gotong royong tercermin dari proses pengolahan bahan, } \\
\text { menghias sajian maulid, mengantar kanre maudu dilakukan } \\
\text { secara bersama-sama dan bekerja sama. } \\
\text { 3. Pembagian Kanre maudu merupakan Semangat untuk } \\
\text { bersedekah yang menjadi bagian tak terpisahkan dari kegiatan } \\
\text { maulid. Masyarakat menyisihan sebagian harta mereka untuk } \\
\text { dijadikan sajian dalam maulid agar bisa dinikmati secara } \\
\text { bersama atas rezeky yang diperoleh selama setahun terakhir. }\end{array}$ \\
\hline 4. & $\begin{array}{l}\text { Nilai-nilai Karakter } \\
\text { yang terkait dengan } \\
\text { kebangsaan, } \\
\text { nasionalisme dan } \\
\text { patriotisme }\end{array}$ & $\begin{array}{l}\text { 1. Setiap anggota keluarga dari berbagai penjuru daerah } \\
\text { berkumpul dan bersama-sama bersatu merayakan maulid. Hal } \\
\text { ini menumbuhkan rasa persaudaraan, kebersamaam, kegotong } \\
\text { royongan, dan persatuan. } \\
\text { 2. Kebersamaan dalam merayakan maulid dilakukan dengan } \\
\text { menyimpan sajian maulid pada satu tempat yang disebut } \\
\text { dengan kandawari dan julung-julung } \\
\text { 3. Rasa cinta terhadap budaya bangsa sendiri merupakan } \\
\text { semangat yang ada dalam diri masyarakat, sehingga rela } \\
\text { mengorbankan harta benda mereka untuk memeriahkan pesta } \\
\text { adat leluhur yang mereka cintai di bumi nusantara. } \\
\text { 4. Pembagian kanre maudu ditujukan pada mereka yang } \\
\text { dianggap berhak, seperti tamu undangan, parate dan } \\
\text { masyarakat yang dianggap membutuhkan makanan pada saat } \\
\text { itu. }\end{array}$ \\
\hline 5. & $\begin{array}{l}\text { Nilai-nilai yang terkait } \\
\text { dengan lingkungan } \\
\text { alam. }\end{array}$ & $\begin{array}{l}\text { 1. kecintaan terhadap alam terkait dengan penyiapan bahan dan } \\
\text { alat yang akan dijadikan sebagai sajian maulid, seperti padi } \\
\text { dan kelapa diwajibkan dari hasil kebun, ladang atau sawah } \\
\text { dan tumbuhan yang ada disekitar lingkungan mereka } \\
\text { 2. wadah menyimpan sajian maulid berupa bakul dan tepa'- } \\
\text { tepa' harus dibuat dari bahan tumbuhan bahan yang disekitar } \\
\text { lingkungan mereka yaitu dari ohon lontar } \\
\text { 3. menjaga kebersihan lingkungan merupakan salah satu yang } \\
\text { harus dilakukan. Seperti ayam akan digunakan sebagai sajian } \\
\text { maulid yang harus bersih dari najis. Ini menandakan bahwa } \\
\text { lingkungan sekitar harus dibersihkan dan terhindah dari najis } \\
\text { atau kotoran yang merusak kesucian bahan-bahan yang akan } \\
\text { dijadikan sajian dalam maulid. . }\end{array}$ \\
\hline
\end{tabular}

\section{KESIMPULAN \& SARAN}

Perayaan budaya lokal merupakan ciri khas suatu masyarakat, perayaan budaya lokal memiliki nilai-nilai atau makna tersendiri bagi masyarakatnya. Perayaan budaya lokal maudu lompoa (maulid besar) yang dilakukan oleh masyarakat Desa Cikoang Kabupaten Takalar yang ditujukan untuk memperingati kelahiran Nabi Muhammad, merupakan suatu perayaan budaya yang dapat membangun karakter bangsa dari setiap tahapan ritual maupun simbol-simbol sajian dari budaya tersebut, 
seperti persatuan, gotong-royong, saling menghargai, perlakuan sama dan setara dan menghargai perbedaan.

Demikian pula perayaan appaddeko yang merupakan perayaan pesta panen yang memiliki kekuatan membangun nilai karakter bangsa. Nilai karakter yang terbangun dalam prosesi perayaan budaya tersebut antara kerjasama, rasa syukur, cinta terhadap alam, kesetaraan, persatuan, solidaritas, kestiakawanan dan lain sebagainya.

Oleh karena itu, apabila suatu bangsa ingin maju, maka lestarikanlah budaya lokal, sebab dalam budaya lokal terkandung nilai dan pesan moral yang dapat dijadikan kekuatan membangun karakter bangsa. Kemajemukan budaya merupakan kekuatan, identitas dan jati diri bangsa, sumber pemersatu, pembangun rasa patriotisme, dan nasionalisme bukan kelemahan, apalagi dijadikan sumber dikriminasi suku dan RAS.

\section{DAFTAR PUSTAKA}

Ihromi, T.O. (2013). Pokok-Pokok Antrologi Budaya. Jakarta: Yayasan Pustaka Obor Indonesia.

Kementerian Pendidikan Nasional, (2010) Pengembangan Pendidikan Budaya Dan Karakter Bangsa, Jakarta: Badan Penelitian Dan Pengembangan Pusat Kurikulum dan perbukuan.

Kementerian Pendidikan Nasional, (2011) Panduan Pelaksanaan Pendidikan Karakter, Jakarta: Badan Penelitian Dan Pengembangan Pusat Kurikulum dan perbukuan.

Megawangi, R. dkk (2004), Pendidikan yang Patut dan Menyenangkan: Penerapan Teori Developmentally Appropriate Practices (DAP). Jakarta: Indonesia Heritage Foundation.

Panjaitan, A.P., Darmawan, A., Maharani, Purba, I.R., Rachmad, Y., Simanjuntak, R. (2014). Korelasi Kebudayan Dan Pendidikan; Membangun Pendidikan berbasis Budaya Lokal. Jakarta. Yayasan Pustaka Obor Indonesia.

Sugiyono. (2013). Metode Penelitian Kuantitatif, Kualitatif dan $R \& D$. Cetakan ke-5. Bandung: CV. Alfabeta.

Wulansari, C. D. 2013. Sosiologi: Konsep dan Teori. Bandung: PT. Rafika Aditama. 